\title{
Bahasa tulis pada anak dengan gangguan disleksia (kajian psikolinguistik)
}

\author{
Sulistiyaning Putri Utami ${ }^{1}$, Lulus Irawati ${ }^{2}$ \\ 1,2) Universitas PGRI Madiun, JI. Setiabudi No. 85 Madiun \\ e-mail: 1)putriutami475@gmail.com; ${ }^{2}$ Iulusirawati@unipma.ac.id;
}

\begin{abstract}
Abstrak
Disleksia adalah salah satu jenis gangguan berbahsa yang dapat menjadi hambatan bagi perkembangan bahasa anak. Disleksia berdampak pada fungsi neurologi otak yang berfungsi untuk pemrosesan bahasa. disleksia juga berdampak pada kemampuan menulis anak. Tujuan dari penelitian ini adalah untuk mendeskripsikan dan menjelaskan bentuk-bentuk bahasa tulis pada anak dengan disleksia. Penelitian ini menggunakan jenis penelitian kualitatif deskriptif. Subjek dalam penelitian ini adalah MNJ, dia adalah siswa kelas dua sekolah dasar. Sumber data dari penelitian ini berasal dari dokumentasi bentuk bahasa tulis dan bahasa lisan dari subjek penelitian. Teknik pengambilan data penelitian ini melalui wawancara, dokumentasi dan pengamatan. Data penelitian ini dianalisis menggunakan reduksi data, sajian data, simpulan dan verifikasi data.hasil temuan dari penelitian ini adalah disleksia menyebabkan beberapa gangguan pada bentuk bahasa tulis anak. Gangguan tersebut antara lain adalah kesalahan menuliskan huruf dalam posisi terbalik, penghilangan huruf, penambahan huruf dan penggantian huruf yang tidak sesuai. Huruf yang ditulis terbalik oleh MNJ berbeda dengan anak disleksia yang lain. Huruf yang sering ditulis secara terbalik adalah $b, d, k, e, a, r, h, s, p$ and t. Meskipun dia memiliki kekurangan dalam kemampuan menulis tetapi MNJ unggul dalam hal menyimak.
\end{abstract}

Kata kunci: bahasa tulis, disleksia

\section{Written language of child with dyslexia syndrome (a psycholinguistic study)}

\begin{abstract}
Dyslexia is one kind of language disorder that can be obstacle for children language development. It can give effect to the neurology's function for processing language. It also gives effect to student's ability in writing. The aim of the research is to describe and explainthe forms of written language in children with dyslexia. This research uses descriptive qualitative research. The research subject is MNJ, students of second grade in Elementary School. The source of the data are documentation of written and oral language from the subject of the research. The techniques of collecting data are observation, interview and documentation. Techniques of analyzing data are data reduction, data display and conclusion drawing or verification. The research findingsare dyslexia causes some disorders in the form of written language. The disorders include writing letter in an inverted position, the omission of letters, making additional and replacement of letters that do not suitable. The letters were written in verse by MNJ different from other dyslexia children. The letters are often in reverse writing is $b, d, k$, $e, a, r, h, s, p$ and $t$. Although he is not good enough in writing skills but MNJ's listening skill is good.
\end{abstract}

Keywords: writing ability, dyslexia 


\section{Pendahuluan}

Kemampuan berbahasa anak dapat ditunjang oleh berbagai macam faktor. Faktor-faktor tersebut antara lain adalah faktor kesehatan dan faktor intelegensi. Dari faktor-faktor tersebut yang paling dominan mempengaruhi kemampuan berbahasa anak adalah faktor kesehatan. Faktor kesehatan dalam hal ini khususnya adalah kesehatan otak. Apabila otak mengalami sebuah ganguan atau penyakit maka bisa dipastikan kemampuan seorang anak dalam berbahasa akan menurun atau bahkan tidak mampu menguasai bahasa sama sekali.

Salah satu bentuk gangguan dalam kemampuan memperoleh dan memproses bahasa adalah disleksia. Disleksia adalah sebuah gangguan fungsi neurologi otak. Penyakit tersebut membuat penderitanya mengalami ketidakmampuan dalam melakukan pengkodean huruf atau mengenali huruf. Seperti yang didefinisikan oleh Orton(1994: 3), "Dyslexia is one of several distinct learning disabilities. It is a specific language-based disorder of constitutional origin characterised by difficulties in singleword decoding, usually reflecting insufficient phonological processing abilities."Lebih lanjut oleh Subyantoro (2013:177) dijelaskan bahwa "disleksia adalah ketidakmampuan mengenal huruf dan suku kata dalam bentuk tertulis." Berdasarkan definisi tersebut dapat diketahui bahwa anak dengan gangguan disleksia hanya tidak mampu mengenali huruf dengan baik apabila huruf tersebut berupa bahasa tulis. Apabila huruf tersebut berbentuk bahasa lisan maka anak disleksia dapat tetap mengenali atau menguasainya dengan baik.

Menulis adalah salah satu komponen berbahasa yang wajib dikuasai anak dalam masa pemerolehan dan perkembangan bahasa. Alek dan Achmad H.P. (2011: 106) menjelaskan bahwa "menulis merupakan suatu kegiatan untuk menciptakan suatu catatan atau informasi pada suatu media dengan menggunakan aksara." Kemampuan menulis ini erat kaitannya juga dengan kemampuan pemahaman tentang bentuk huruf dan cara penulisannya. Apabila menulis ini dikaitakan dengan kemampuan penjebaran ide maka dibutuhkan juga kemampuan mengeja kata yang akan dituliskan.

Pada beberapa jenis kasus gangguan berbahasa perkembangan kemampuan menulis menjadi terhambat. Seperti yang terjadi pada anak dengan gangguan disleksia. Ciri-ciri anak disleksia yang mudah diketahui adalah kelemahan dalam hal menulis. Anak disleksia cenderung memiliki tulisan tangan yang buruk, sering menuliskan huruf dalam posisi yang terbalik, kesulitan mengeja dan mudah terganggu konsentrasinya (Subyantoro, 2013:193). Secara lebih spesifik, dalam penelitian yang ditulis oleh Madinatul Munawaroh dan Novi Trisna Anggrayni menyebutkan bahwa kesalahan penulisan secara terbalik banyak terjadi pada huruf-huruf yang hampir mirip bentuknya atau bayangannya pada cermin. Huruf tersebut antara lain adalah $b-d, p-q$ dan 3-E (Munawaroh dan Anggrayni, 2012:170). Kondisi tersebut diperparah dengan ketidak mampuan anak disleksia untuk mengeja kata menjadi suku kata. Seperti yang dijelaskan oleh Orton(2014:3) anak disleksia mengalami kesulitan dalam hal mengidentifikasi atau mengitung suku kata.

Berdasarkan penjelasan di atas, peneliti melakukan penelitian dengan judul "Bahasa Tulis pada Anak dengan Gangguan Disleksia (Kajian Psikolinguitik)". Penelitian ini bertujuan untuk mendeskripsikan dan menjelaskan bentuk-bentuk bahasa tulis pada anak dengan gangguan disleksia. Diharapkan penelitian ini dapat menambah informasi tentang kemampuan bahasa tulis pada anak disleksia mengingat bahwa disleksia adalah bentuk gangguan berbahasa yang masih jarang diketahui oleh publik.

\section{Metode Penelitian}

Penelitian ini menggunakan jenis penelitian kualitatif deskritif. Dimana peneliti secara terperinci menjelaskan fenomena yang berkiatan dengan bentuk-bentuk bahasa tulis anak dengan gangguan disleksia. Penelitian dilaksanakan selama 6 bulan. Subjek 
penelitian ini adalah seorang anak berusia 8 tahun berinisia MNJ. Sumber data dalam penelitian ini diambil dari tiga aspek yaitu: situasi sosial, informan dan dokumen. Situasi sosial yang digunakan adalah lingkungan sekolah tempat MNJ bersekolah. Informan dalam penelitian ini hanya satu anak yaitu MNJ. Sedangkan untuk dokumen diambil dari dokumentasi bahasa tulis dari subjek penelitian.

Teknik pengumpulan data yang digunakan dalam penelitian ini adalah wawancara, dokumentasi dan pengamatan. Wawancara dilakukan dengan orang tua dan guru dari subjek penelitian. Dokumentasi yang dipergunakan adalah hasil pengambilan data bahasa tulis dari subjek penelitian. Dalam penelitian ini, diamati tingkah laku dan kegiatan subjek penelitian baik di dalam maupun di luar kelas. Pada pengambilan data bahasa tulis, peneliti terlebih dahulu menyiapkan sejumlah kalimat yang akan didektekan kepada subjek penelitian. Kalimat yang dipergunakan sudah disesuaikan dengan kemampuan menulis anak seusianya. Kalimat-kalimat tersebut kemudian didektekan kepada subjek penelitian tanpa batasan waktu dalam penulisannya. Peneliti memberikan keluasaan kepada subjek penelitian untuk mengeja terlebih dahulu sebelum menuliskannya. Pada penelitian ini penelitian ini peneliti menggunakan triangulasi data untuk melakukan verfikasi data yang digunakan. Sedangkan untuk teknik analisis data, digunakan tiga tahapan yaitu reduksi data, sajian data, verifikasi dan simpulan.

\section{Hasil dan Pembahasan}

Di bawah ini akan dijelaskan bentuk-bentuk bahasa tulis dari subjek penelitian. Temuan penelitian tersebut kemudian akan dideskripsikan menurut jenisnya masingmasing.

\section{Penulisan Huruf Secara Terbalik}

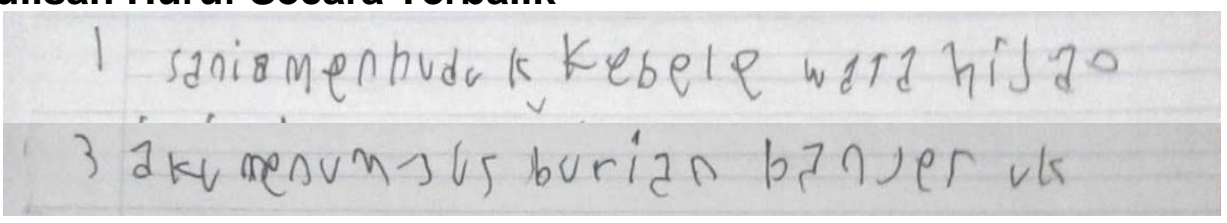

Gambar 1. Temuan Penulisan Huruf Terbalik

Pada kalimat pertama, Sania menumbuk kedelai warna hijau. Kesalahan terjadi pada kata "menumbuk" yaitu b ditulis secara terbalik dan pada kata "kedelai" huruf d ditulis secara terbalik. Pada kalimat ke dua, aku minum jus durian dan jeruk. Kesalahan terjadi pada kata "durian" huruf d ditulis secara terbalik dan pada kata "dan" huruf $d$ juga ditulis secara terbalik. Dari keseluruhan data yang didapatkan oleh peneliti, huruf yang dominan mengalami kesalahan dalam penulisan adalah $b$, $\mathrm{d}, \mathrm{p}, \mathrm{q}, \mathrm{k}, \mathrm{h}, \mathrm{e}, \mathrm{r}$ dan $\mathrm{s}$.

\section{Penghilangan Huruf}

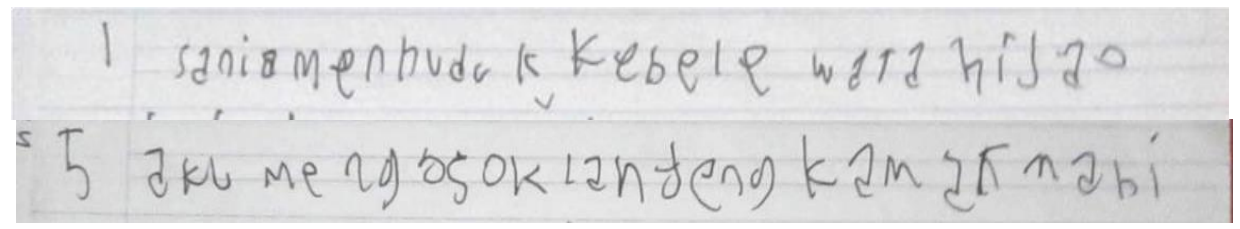


Gambar 2. Temuan Penghilangan huruf

Pada kalimat pertama, Sania menumbuk kedelai warna hijau, terjadi dua kesalahan". Kata "menumbuk" menjadi "menuduk" dan kata "warna" menjadi "wara". Pada kalimat ke dua, aku menggosok lantai kamar mandi, terdapat dua kesalahan. Kata "menggosok" menjadi "mengosok". Kata "mandi" menjadi "mabi". Kata-kata yang hilang hurufnya cenderung adalah kata-kata yang panjang atau kata-kata yang terdiri dari lebih dua suku kata. Merujuk pada hasil wawancara dengan guru MNJ didapati temuan bahwa MNJ di kelas memang sering menuliskan sebuah kata secara tidak utuh bahkan kadang bukan hanya huruf di tengah saja yang hilang.

\section{Penambahan Huruf}

Berdasarkan keseluruhan data yang dikumpulkan oleh peneliti dapat terlihat bahwa kesalahan penambahan huruf tidak dipengaruhi oleh panjang pendek kata yang ditulis. Seperti pada kalimat di bawah ini.

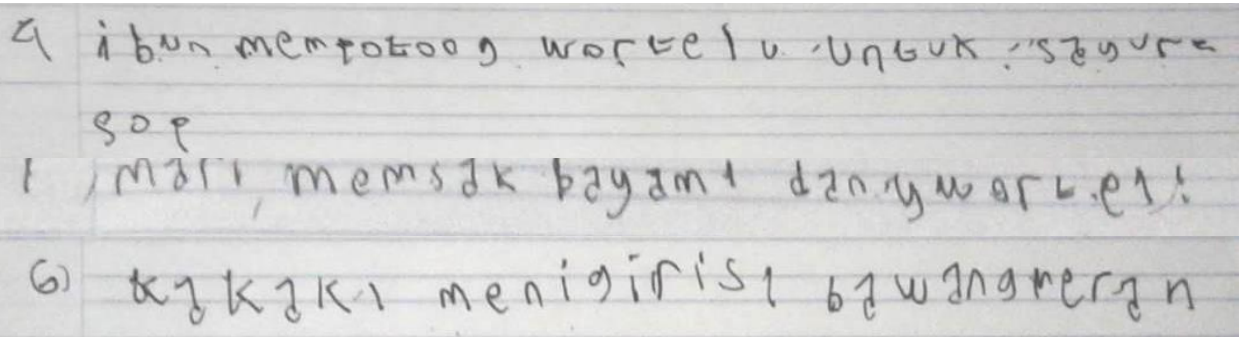

Gambar 3. Temuan Penambahan Huruf

Pada kalimat, "ibu memotong wortel untuk sayur sop". Kata "ibu" menjadi "ibun". Penambahan huruf sebagian terjadi di akhir kata. Contohnya pada kalimat pertama, mari memasak bayam dan wortel. Kata "dan" menjadi "dany". Kata "wortel" menjadi "worteli". Pada kalimat yang lain terlihat adanya pengaruh pengucapan pada terjadinya kesalahan penambahan huruf. Contohnya kalimat, kakak mengiris bawang merah. Kata "mengiris" menjadi "meningiris".

\section{Penggantian Huruf}

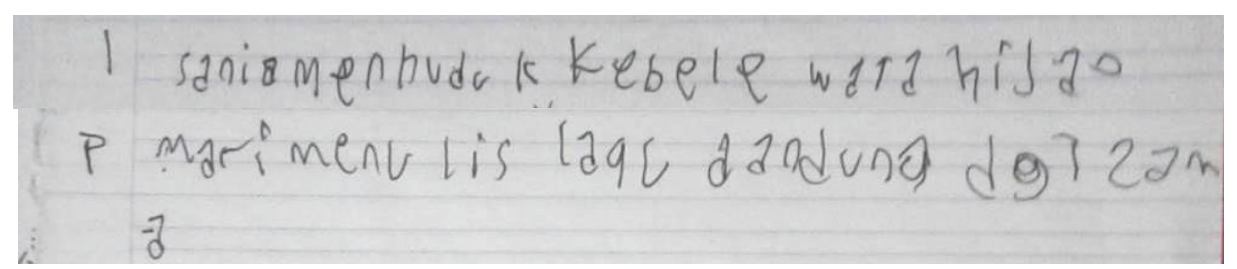

\section{Gambar 4. Temuan Penggantian Huruf}

Pada kalimat pertama, Sania menumbuk kedelai warna hijau, terdapat satu kesalahan. Huruf u pada kata "hijau" diganti dengan huruf o. Adanya penulisan tersebut dapat terjadi karena pengaruh pengucapan bahasa Jawa. Bahasa Jawa adalah bahasa ibu atau bahasa pertama dari subyek penelitian. Selanjutnya pada kalimat ke dua, mari menulis lagu dangdut bersama, terdapat satu kesalahan yaitu pada kata "dangdut". Kesalahan ini dapat terjadi karena secara pengucapan "dangdut" dan "dangdung" itu hampir sama. Masalah itu juga dikarenakan MNJ mungkin asing dengan ejaan kata dangdut.

Berdasarkan analisis data hasil penelitian, ada beberapa gejala gangguan berbahasa yang muncul pada subjek penelitian. Gangguan berbahasa tersebut antara lain adalah penulisan huruf secara terbalik, 
penambahan huruf, penghilangan huruf dan penggantian huruf. Kesalahan penulisan huruf secara terbalik menjadi yang paling dominan terjadi di antara yang lain. Mengenali huruf secara terbalik adalah salah satu ciri khas anak disleksia.

Anak disleksia memiliki kecenderungan untuk mengenali huruf secara terbalik. Hal tersebut konsisten terjadi baik pada bahasa lisan maupun bahasa tulis. Keadaan tersebut lebih lanjut dijelaskan oleh Orton. Orton (1994:2) mendeskripsikan disleksia sebagai berikut.

"Dyslexia is a specific learning disability that is neurological in origin. It is characterized by difficulties with accurate and/or fluent word recognition and by poor spelling and decoding abilities. Secondary consequences may include problems in reading comprehension and reduced reading experience that can impede the growth of vocabulary and background knowledge."

Dari definisi tersebut dapat diketahui bahwa, anak disleksia memang mengalami kesulitan dalam hal pengkodean huruf dan mengeja. Kedua kesulitan tersebut adalah akibat dari kurangnya kemampuan dalam hal fonologi yang tanpa disadari berpengaruh terhadap kemampuan kognitif seorang anak.

Dalam penelitian yang ditulis oleh Madinatul Munawaroh dan Novi Trisna Anggrayni menyebutkan bahwa kesalahan mengenali huruf banyak terjadi pada huruf-huruf yang hampir mirip bentuknya atau bayangannya pada cermin. Huruf tersebut antara lain adalah b-d, p-q dan 3-E (Munawaroh dan Anggrayni, 2012:170). Berbeda dengan penelitian tersebut dari hasil penelitian yang dikumpulkan oleh peneliti menyebutkan bahwa MNJ melakukan kesalahan penggunaan huruf secara terbalik pada huruf $b, d, k, e, a, r, h, s$, dan t. Untuk huruf $k, e, a, r, h, s$, dan t tidak memiliki pasangan huruf yang bentuknya hampir sama dalam urutan alfabet.

Pada penelitian tersebut tidak disebutkan siapa subjek penelitiannya. Simpulan bahwa huruf-huruf yang terbalik adalah dominan huruf yang hampir sama bentuknya dengan huruf lain belumlah tepat. Berbeda dengan penelitian ini dimana peneliti telah secara jelas menyebutkan karakteristik dari subjek penelitian. Namun, perlu disadari bahwa setiap anak disleksia adalah unik bahwa masing-masing dari mereka memiliki karakteristik masing-masing begitu pula ketika mengenali huruf.

Pada setiap anak disleksia, masalah huruf apa yang dikenali secara terbalik bisa saja berbeda. Hal ini dibuktikan dari pernyataan Subyantoro (2013:193) tentang ciri-ciri anak disleksia salah satunya adalah sering keliru dengan huruf-huruf tertentu contohnya ' $b$ ' dianggap ' $p$ ' dan ' $p$ ' dianggap ' $q$ '. Sedangkan pada MNJ huruf yang banyak terbalik justru adalah b, $d, k, e, r, h, s$ dan a. Temuan ini membuktikan bahwa setiap anak disleksia adalah unik. Masing-masing dari mereka memiliki kemampuan yang berbeda dalam mengenali sebuah huruf.

Dalam bahasa tulis yang menjadi gangguan berbahasa tidak hanya masalah penulisan huruf secara terbalik tetapi juga adanya masalah lain seperti penghilangan huruf, penambahan huruf dan penggantian huruf. Hasil temuan peneliti ini ternyata sama dengan apa yang termuat pada penelitian yang ditulis oleh Munawaroh dan Anggrayni. Pada penelitian tersebut disebutkan bahwa anak-anak disleksia cepat dalam mengeja namun banyak membuat kesalahan 
seperti dalam hal penghilangan, penambahan dan penggantian huruf. Menurut Munawaroh dan Anggrayni hal tersebut terjadi sebagai akibat kesulitan mengeja. Kondisi tersebut mengakibatkan mereka membuat karangan atau mengarang kata yang tidak sesuai dengan yang seharusnya (Munawaroh dan Anggrayni, 2012:171).

Selain karena kurangnya kemampuan dalam hal mengeja kata, dilihat dari jenis kesalahan yang terjadi dapat diketahui ada faktor rendahnya konsentrasi MNJ dalam menulis. Masalah rendahnya konsentrasi anak disleksia juga didukung oleh pernyataan dari ahli sebagai berikut. Subyantoro (2013:193) menyatakan bahwa, "anak disleksia cenderung memiliki perhatian mudah terganggu atau gagal untuk menyelesaikan pekerjaan sampai tuntas." Masalah ini terutama sering terjadi apabila berkaitan dengan kegiatan menulis dan membaca. Huruf menjadi semacam momok yang membosankan dan cukup menakutkan bagi anak disleksia.

Seperti yang telah dijelaskan dalam uraian di atas bahwa anak disleksia sering mengalami kesalahan dalam hal menulis. Itulah mengapa diperlukan perhatian khusus yang diberikan oleh guru kepada anak tersebut. Pada dasarnya anak disleksia memiliki kemampuan yang sama seperti anak-anak yang lain namun mereka memiliki cara yang berbeda dalam belajar. Begitu pula yang disebutkan oleh Olagboyega dalam penelitiannya. Beliau menyatakan bahwa kesalahan mengeja harus ditanggapi secara lebih bijaksana oleh guru. Selama apa yang dituliskan oleh siswa masih bisa dipahami oleh guru. Guru jangan terlalu berfokus pada aspek morfologi namun bagaimana siswa telah berusaha menuliskan sesuatu sesuai kemampuannya. (Olagboyega, 2008:25)

Meskipun MNJ lemah dalam hal menulis dan membaca, dia tetaplah memiliki kelebihan. Kelebihannya adalah dalam hal menyimak, seperti yang disebutkan pada analisis data hasil penelitian yang menyebutkan MNJ adalah tipe anak auditori. Temuan tersebut juga sesuai dengan ciri-ciri anak disleksia yang disebutkan oleh Irlen (1998:12) bahwa anak disleksia lebih menyukai mendengar dari seseorang yang membacakan untuk mereka. Berdasarkan dari pernyataan tersebut jelaslah bahwa memang anak disleksia memiliki ketertarikan dalam hal menyimak, karena pada jenis kemampuan menyimak tidak dibutuhkan interaksi dengan huruf

\section{Kesimpulan}

Berdasarkan keseluruhan uraian di atas dapat disimpulkan bahwa setiap anak disleksia adalah individu yang unik. Masing-masing mereka memiliki kemampuan yang berbeda dalam hal mengenal huruf dan mengingatnya. Sehingga tidak dapat disamakan antara satu anak disleksia dengan anak disleksia lainnya. Meskipun begitu mereka sebagian besar tetap memiliki ciri-ciri yang sama antar lain menulsikan huruf secara terbalik, mengurangi huruf ketika menulis, menambah huruf ketika menulis dan mengganti huruf ketika mereka lupa huruf apa yang harus dituliskan. Anak disleksia dengan semua keunikkannya membutuhkan pemahaman dari pendidiknya sehingga akan mempermudah dalam proses belajar mengajar anak disleksia. Guru sebaiknya lebih berfokus pada maksud dari tulisan anak disleksia dari pada ketepatan penulisan huruf yang mereka gunakan.

Pada penelitian ini, jangka waktu penelitian kurang lebih hanya enam sehingga kurang dapat dijelaskan secara lebih terperinci dan kompleks mengenai macammacam denomena yang terjadi pada bentuk-bentuk bahasa tulis anak disleksia. Sehingga akan lebih baik untuk peneliti-peneliti selanjutnya yang akan meneliti hal 
serupa untuk dapat meneliti anak disleksia dalam kurun waktu yang lebih lama sehingga dapat diperoleh data yang lebih kompleks.

\section{Daftar Pustaka}

Alex \& Achmad, H.P. (2011). Bahasa Indonesia untuk Perguruan Tinggi. Jakarta: Kencana Prenada Media Group.

Munawaroh, M \& Anggrayni, N.T. (2008). Mengenali Tanda-Tanda Disleksia Pada Anak Usia Dini. (Online). (http://repository.upy.ac.id/409/1/artikel\%20madinatul.pdf diunduh 3 Oktober 2016).

Olagboyega, K. (2008). The Effects of Dyslexia on Language Acquisition and Development. Vol 29. No 10. Halaman 29.

Orton. (2014). IDA Dyslexia handbook What Evry Family Should Know, Baltimore: International Dyslexia Association.

Subyantoro. (2013). Gangguan Berbahasa. Yogyakarta: Penerbit Ombak. 